\title{
If You Do not Like Selling Passports, Give Them for Free to Those Who Deserve Them
}

\author{
Vesco Paskalev
}

The Maltese idea to 'sell' citizenships was met with almost universal criticism, not only within our Forum discussion but throughout Europe. While it is difficult to disagree with most of the arguments against monetization of citizenship, in my view they all aim at the wrong target. It is not the sale of citizenship per se which violates principles of justice and democracy; it is the existing international system of inclusion and exclusion of third country nationals which is deeply skewed and denigrates the value of citizenship. For all that I know, even the ultra-rich do not easily throw $€ 650,000$ to the wind, so a condition under which anyone would give huge amounts of money for a travel document is deeply troubling. It is not membership but mobility which is at issue. Moreover, as Paulina Ochoa aptly notes, not only the rich but also the poor seek naturalisation for economic rather than civic reasons.

Bauböck distinguishes two sides of citizenship - an internal and an external one. Focusing on the former, he persuasively argues that selling citizenship undermines democracy. In a similar vein, Dzankic notes that in some cases the very fact of putting a price to a good corrupts the good. As a decent republican I fully agree with both of them. But as Spiro notes, the corruption of this good may have started long ago for reasons which have nothing to do with the recent fashion of investor citizenship schemes. While the policy makers and academics were predominantly concerned with the internal aspect of citizenship, various forces - from the Schengen Agreement via Ryanair to Moneygram - have brought the external aspect to the fore.

Is citizenship all about travel indeed, or about identity and democracy? A natural experiment occurred between Bulgaria and Macedonia. Most Bulgarians believe that Macedonians are actually ethnic Bulgarians, who happen to live in an artificial country because of some historic contingencies. Naturally, most Macedonians are annoyed (to put it mildly) by that suggestion and vehemently assert their Macedonian identity against Bulgarian imperialism. Yet, when Bulgaria joined the EU, Macedonians 
flocked to the Bulgarian consulates to apply for a passport. Suddenly, thousands were claiming that they are 'of Bulgarian origin'. Very few of these people had any actual bonds with Bulgaria and it is difficult to believe that anyone had suddenly woken up to her or his true Bulgarian identity. Apparently their Macedonian self-consciousness was in harmony with a Bulgarian passport and the opportunities it gives to 'Bulgarians abroad'.

I hasten to add that Macedonia tolerates dual citizenship; if people had to renounce their Macedonian citizenship in order to obtain a Bulgarian passport, the numbers could be very different. Yet, the story is telling. It shows how easy it is for people to claim certain origins when this is convenient despite of firmly holding on to a different identity, which in the Macedonian case has been explicitly constructed as excluding the Bulgarian one. For all the value we attach to citizenship, the relative weight of its internal aspect is by far superseded by that of its external dimension. When asserting that a passport is more about travel than about anything else I am not being cynical - most citizens do care about membership, too. But when your passport matters so much outside of your country, you are under pressure to adjust your priorities. Thus, in the extreme case, your passport may be completely unrelated to your emotional belonging. Virtually all countries in the world discriminate among those wishing to enter on the basis of the completely arbitrary facts of their birthplace and descent. It is this arbitrariness which corrupts the value of citizenship (and by implication of domestic democracy), not the availability of a bypass or two for a tiny minority, be it rich or poor.

So what should an EU Member State do in the face of the Maltese scheme if it is concerned with rescuing the value of citizenship as Shachar pleads? For sure, trying to prevent the Maltese from making some cash from a system which is already so unjust and distortive would not help much. Yes, selling citizenship does not do anything to help either, but if a wealthy European democracy is truly appalled by the idea of selling passports to the rich, why not start giving its passports for free to a more deserving crowd? The only decent response to the opening of a mobility corridor for the rich would be to open mobility corridors for the righteous - those who have shown exemplary civic virtue, have made sacrifices for democracy or human rights or are subject to outrageous persecution. A tentative list of candidates would include convicted Russian punks, jailed Egyptian protesters and Chinese dissidents, American whistle-blowers, Iranian adulterers facing stoning, etc. Certainly, one can immediately think about a number of problems that such a policy could create, yet if Raoul Wallenberg took the risk of 
handing out Swedish passports to save hundreds of Hungarian Jews from the Nazis, why shouldn't a proud member of the EU do something similar?

In practical terms granting citizenship to prominent civil rights activists can spare them from persecution at home and provide them with a mobility corridor to the Western world. Symbolically, it can become a way of recognition of their civic virtues and exploits (certainly, despotic regimes may frame it as evidence for treason). Critics are right to claim that the very fact that an immaterial value has a price tag undermines it, but the opposite can also be true - giving passports to highly esteemed figures can make these passports highly esteemed, too. If you are rich, go get a passport from Malta! If you are righteous, maybe you should be able to get a passport from say, Sweden. Comparing the existing investor citizenship schemes, the Financial Times feared that selling citizenship may start a race to the bottom. ${ }^{1}$ Why not try launching a race to the top instead?

Open Access This chapter is licensed under the terms of the Creative Commons Attribution 4.0 International License (http://creativecommons.org/licenses/by/4.0/), which permits use, sharing, adaptation, distribution and reproduction in any medium or format, as long as you give appropriate credit to the original author(s) and the source, provide a link to the Creative Commons license and indicate if changes were made.

The images or other third party material in this chapter are included in the chapter's Creative Commons license, unless indicated otherwise in a credit line to the material. If material is not included in the chapter's Creative Commons license and your intended use is not permitted by statutory regulation or exceeds the permitted use, you will need to obtain permission directly from the copyright holder.

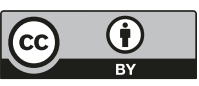

1 “"Passport for sale" plan raises concern among EU members', Financial Times, 9 December 2013, available at https://www.ft.com/content/b8a2adfa-6106-11e3b7f1-00144feabdc0 